\author{
Arkadiusz Morawiec \\ Uniwersytet Łódzki \\ arkadiuszmorawiec@poczta.fm
}

\title{
The Holocausts
}

Abstract: Morawiec Arkadiusz, The Holocausts. "Poznańskie Studia Slawistyczne" 12. Poznań 2017. Publishing House of the Poznań Society for the Advancement of the Arts and Sciences, pp. 225-239. ISSN 2084-3011.

The article examines genocide as a category that has been used and abused in various, especially historical, political, and ideological, discourses. It considers whether the extermination of Jews (the Holocaust) should be studied in the context of other mass crimes. I investigate various sources of twentieth-century organized violence and their literary representations. I also discuss the works of Polish literature (by Nałkowska, Gębarski, Woroszylski, and Margolis), which depict twentieth-century acts of genocide (the extermination of Jews and Armenians, in particular) in the context of other mass crimes.

KEYWORDS: genocide; Holocaust; Armenian Genocide; historiography; collective memory; literature

The word "holocaust" is sometimes used as a synonym of genocide. Written with a capital letter, it refers first and foremost to the extermination of Jews by Germans (Nazis) during the Second World War. Sometimes the term also denotes mass murders of Gypsies, Poles, representatives of other Slavic nations, and of neurodiverse people committed in the same period. In his Nobel Lecture delivered in 1980, Czesław Miłosz stated:

We are surrounded today by fictions about the past, contrary to common sense and to an elementary perception of good and evil. As "The Los Angeles Times" recently stated, the number of books in various languages which deny that the Holocaust ever took place, that it was invented by Jewish propaganda, has exceeded one hundred. If such an insanity is possible, is a complete loss of memory as a permanent state of mind improbable? And would it not present a danger more grave than genetic engineering or poisoning of the natural environment?

For the poet of the "other Europe" the events embraced by the name of the Holocaust are a reality, so close in time that he cannot hope to liberate himself from their remembrance unless, perhaps, by translating the Psalms of David. He feels anxiety, though, when the meaning of the word Holocaust undergoes gradual modifications, so that the word begins to belong to the history of the Jews exclusively, as if among the victims there were not also millions of Poles, Russians, Ukrainians and prisoners of other na- 
tionalities. He feels anxiety, for he senses in this a foreboding of a not distant future when history will be reduced to what appears on television, while the truth, as it is too complicated, will be buried in the archives, if not totally annihilated. Other facts as well, facts for him quite close but distant for the West, add in his mind to the credibility of H.G. Wells' vision in The Time Machine: the Earth inhabited by a tribe of children of the day, carefree, deprived of memory and, by the same token, of history, without defense when confronted with dwellers of subterranean caves, cannibalistic children of the night (Miłosz 1994: 194).

Fortunately, the negationists, who question the extermination of Jews, constitute (and hopefully will still constitute) a very small minority. Besides, more and more books which unearth other mass murders have recently been published, also in Poland (and Miłosz would be probably very glad to hear this). One of them is Richard C. Lukas's book with a telling title The Forgotten Holocaust: the Poles under German Occupation. One could also mention scholarly works, as well as reportages and memoirs examining various acts of genocide committed in the close or distant past, or in contemporary times. Let me offer a few examples of books that have been translated into Polish: King Leopold's Ghost: a Story of Greed, Terror, and Heroism in Colonial Africa by Adam Hochschild, The Kaiser's Holocaust: Germany's Forgotten Genocide and the Colonial Roots of Nazism by David Olusoga and Casper W. Erichsen, Gulag: a History by Anne Applebaum, Terra Nullius: a Journey through No One's Land by Sven Lindqvist, The Armenians: History of a Genocide by Yves Ternon, and Machete Season: the Killers in Rwanda Speak by Jean Hatzfeld. More and more publications point to the roots of these acts of murder, including the act that is most well-known among Western readers - the extermination of European Jews. The Origins of Nazi Violence (2003) is a precious book in this respect. Considering Nazism and the extermination of Jews as a unique crime, the author, Enzo Traverso, shows their pre-history, which goes beyond the geographical and temporal boundaries of Germany and the $20^{\text {th }}$ century. Traverso argues that the Counter-Enlightenment, the völkisch movement, and antisemitism were not the only factors that contributed to Endlösung der Judenfrage. It (along with many other phenomena) was also influenced by the guillotine (which started "the era of serialized death"), the mechanization of work and turning it into a means of persecuting and humiliating prisoners, bureaucratization, colonialism and imperialism, the development of modern technology and science, 
including eugenics, the anthropology of races, social Darwinism, and the First World War (including its massacres). I would also like to add that more often than before scholars discuss the extermination of Jews from the comparatist perspective: they contextualize it.

It seems that the perception of the extermination of Jews and our times, in general, as particularly terrible is the result of our short-sightedness and the distance from other epochs and their crimes. The biblical Book of Numbers describes the annihilation of the Amalekites and Midianites. In The History of the Peloponnesian War, Thucydides writes about the massacre of the Mytilenians perpetrated by the Athenians in 416 BCE. Published in 1552, Bartolomé de las Casas's A Short Account of the Destruction of the Indies is also an informative and depressing document to read. In the $19^{\text {th }}$ and at the beginning of the $20^{\text {th }}$ centuries, mass murders were committed, for instance, in Africa: e.g., at the turn of the past century, the German Colonial Army systematically exterminated the Herero and the Nama people. These and other crimes, including the later instances of genocide, did not, however, cause as much shock in members of Western societies as the mass extermination of Jews, the Holocaust. In spite of some historians' attempts to contextualize it, the Holocaust tends to be seen as one of a kind, as a terrible singular event, and also as a "paradigm" of genocide.

Referring to the Second World War, Wanda Kiedrzyńska states: "In the history of humankind, it is a period without a precedence. Even the times of slavery did not witness such degradation of human dignity as the one that took place in Europe and was caused by Nazi Germany. The system that was introduced in the camps was a hundred times worse than slavery" (Kiedrzyńska 1947: 161). One may, however, ask whether Kiedrzyńska, a former inmate of Frauenkonzentrationslager Ravensbrück, does not use a hyperbole in this fragment, which belittles the suffering caused by slavery. Alain Besançon rightly advises that we should resist the temptation of considering one form of death as more cruel than another, since we do not have a first-hand experience of either: "No one knows what a child felt while inhaling Zyklon B or dying of hunger in an Ukrainian cottage [during the Soviet famine]. Since people were killed outside any law, one should conclude that they all suffered horrible deaths since all of them were innocent. (...) classifying their suffering is impossible and improper" (Besançon 2000: 25). 
Let me highlight that my argument is not about the terminology. It is not my aim to decide whether the use of the term "Holocaust" is welljustified in relation to "the Poles under German occupation" or to native Americans, for instance in David E. Stannard's book American Holocaust, in the title of the above-mentioned book by Olusoga and Erichsen Kaiser's Holocaust, or in the French subtitle of Adam Hochschild's work describing the demise of several millions of Congolese people caused by Belgians - Un holocauste oublié. Like "genocide", "holocaust" ("Holocaust") is a contentious term. I am neither concerned with the theological nor the political aspects of this debate. I leave to others, especially to lawyers and historians, the terminological dispute on whether, for instance, the Soviet famine in Ukraine or the Katyn massacre are instances of genocide in the light of Rafał Lemkin's definition of the term and the definition put forward in the UN Convention in 1948. To paraphrase Tadeusz Różewicz's poem Ocalony (The Survivor), I would say that in the context of this study, "genocide", "genocidal activities", "ethnocide", "ethnic cleansing", "extermination", "massacre", "deportation", "clearance", and similar (often contentious!) terms, when used in reference to the reality of a mass murder, are for me "only words". I want to address a different issue.

I wish to make scholars (also those who specialize in literature) aware of the fact that the extermination of Jews - which has rightly been given proper attention, because it happened here (in the heart of Europe) not long ago - is "just" one of many exterminations, instances of "mass violence". I am far from relativizing the Nazi extermination of Jews; I am aware of its specificity. I only wish to accentuate the fact that genocidal practices have been common and have repeatedly recurred in our history (and they are "recorded" in literature). It is also a common human propensity to consider our suffering as more tragic than the suffering of others. This concerns not only individuals, but also whole nations. For many years, Poland has been witnessing an uneven fight between Poles and Jews, who both claimed "primacy in suffering". When Poland was governed by communists, it was often "forgotten" that Polish (and non-Polish) Jews were mostly killed because they were Jews rather than

\footnotetext{
${ }^{1}$ Coined by Jacques Semelin (2003: 354-355), the term "mass violence" seems much more accurate than "genocide".
} 
Poles or Polish citizens. The first monuments in the former death camps in Chełmno (Kulmhof), Bełżec, Sobibór, and Treblinka were erected as late as in the 1960s. The fact that almost all people who died there were Jews was not usually mentioned. The propaganda of the Polish People's Republic preferred to speak about "victims of many nationalities". For many decades, the suffering of the Polish nation remained in the foreground. In the recent years, the extermination of Jews has been brought to light, which is good. However, people still know very little about the mass murders that were committed earlier, or simultaneously, or later. Of course, we have heard about slavery, imperialism, and colonialism. As early as more than a hundred years ago, Poles read Sienkiewicz's novella Sachem, whose protagonist is a representative of a perishing Native American community. Still, most of them rightly perceived it as an allusion to the history of Polish people, who were oppressed by Prussian authorities (Bujnicki 1986: LXXX). Much time had passed before we saw these "red-skinned barbarians", who were very rarely described as "noble savages", as primarily victims.

Thus, I would like to suggest that we should look at the Holocaust (and, simultaneously, at the terrible experiment of communism) from proper distance, without inadequate emotional responses, and "in context"; we should not perceive these historical events as fully unique. In his book The Age of Genocide, Bernard Bruneteau states: "Extermination practices have a long history and we can find their traces in most ancient communities" (Bruneteau 2005: 13). Bruneteau enumerates these traces and, in subsequent chapters, analyzes those that have anticipated the terrible events of the twentieth century, e.g. the extermination of Armenians, the genocide of Ukrainian people by the Soviet Union (Joseph Stalin), the extermination of Jews, the crimes committed by the Khmer Rouge, the "ethnic cleansing" in Bosnia, and the genocide in Rwanda. A similar tendency to compare these and other similar events is conspicuous in Manus I. Midlarsky's book The Killing Trap: Genocide in the Twentieth Century (2005), and in Daniel Jonah Goldhagen's work Worse than War: Genocide, Eliminationism, and the Ongoing Assault on Humanity (2009). Yet, the connections between twentieth-century and older crimes have not been noticed exclusively by historians. They have also been described by writers (many of whom created their works long ago!). Let me offer a few examples. 
In his essay Podobny do bogów (Similar to Gods) Mieczysław Jastrun argues (1962: 13-14) that if one analyzes Homer's epic poems in a clear-headed way, one will find in them "all crimes of our times, interconnected and told in the seductive language of poetry". Jastrun also encourages his readers to familiarize themselves with the equally informative text by Thucydides: "One should read this profound and objective history of the Peloponnesian War, in order to find all the madness, betrayal, and also genocide of contemporary times in this Mediterranean miniature". Jastrun perceives the quarry that was transformed by the Syracusans into a very harsh place of incarceration for Athenian prisons of war as the "first concentration camp", which could well be the pride of the British general Lord Kitchener, who became infamous for his cruelty during the wars with the Mahdists and the Boers, or even of Himmler himself". In his memoir (1953) entitled Inny Świat (A World Apart: the Journal of a Gulag Survivor), Gustaw Herling-Grudziński (Gustav Herling) mentions that there is a continuity between the penal servitude depicted in Fyodor Dostoevsky's Записки из Мёртвого дома (The House of the Dead) and Soviet gulags. Michał Głowiński also states that Franz Kafka's In der Strafkolonie (In the Penal Colony) "foresaw the institutions of organized cruelty which were founded more than a dozen years after it was written" (Głowiński 1998: 57). This statement is not, however, precise: Kafka was not a prophet. In 1914, when he was writing his famous short story, various "institutions of organized cruelty" have already been operating. We know them from historiography as well as from literature. It should suffice to mention the shocking description of the infliction of corporal punishment on a prisoner in Anton Chekhov's reportage Остров Сахалин: Из путевых записок (The Island: a Journey to Sakhalin) which was published in the years 1893-1894 (and his earlier short story Палата No. 6 [Ward No. 6], which was most probably inspired by Chekhov's visit to Sakhalin) ${ }^{2}$, and the novella Heart of Darkness by Joseph Conrad, published in 1899 (and the short story An Outpost of Progress, which anticipated it).

2 "A thread runs from ward No. 6 through penal servitude towards the whole Russia" (Śliwowski 1986: 224). In his preface to Chekhov's selected short stories, Śliwowski calls Ward No. 6 "prophetic" (Śliwowski 1989: LIV). In 1982, the author of Колымские рассказы (Kolyma Tales) Varlam Shalamov died in the painfully real ward No. 6. 
We have more and more evidence at our disposal (if we look into books on various acts of genocide), which shows that Dostoevsky, Chekhov, Conrad, and Kafka drew their conclusions from experience or from the facts of which they had heard. We, Western citizens, perceive the above-mentioned writers only as "prophets", because we lack a broader perspective. We tend to forget many past events, which are more distant that Soviet gulags and the Shoah, or erase them from our memory. This "repression" (Verdrängung) was also instigated by the shock caused by the Second World War and, in case of some nations, the guilty conscience of colonizers. However, as Bruneteau argues,

The twentieth-century violence was well-prepared. It has (...) its "roots" - not so much causes, but rather various elements which crystalized to become its integral components - in the whole history of the $19^{\text {th }}$ century. The terror of genocide reveals its own past - imperialism and "total war." The times of imperialism, when the new racist ideas justified bloody colonial expansion, mark the beginning "administrative massacres". The Great War, which witnessed the bestialization of the enemy, extreme violence, and mass death, led to the brutalization of European societies. These elements formed the intellectual, social, and political foundations of the later complacent denial of human rights (Bruneteau 2005: 29).

Not many Polish readers remember Zofia Nałkowska's 1927 "international novel" entitled Choucas. One of its crucial motifs is the Turkish extermination of Armenians, which began in 1915 (and the massacres that anticipated it, which took place several and more than a dozen years earlier). One of the characters in the novel, who has survived the extermination, complains to the narrator:

(...) if only I could really believe back then that what happened in Armenia was a standalone event, an incomprehensible mistake... If only I could be certain that this contradicts the order of the world, that it puts its harmony in danger... But this was in accordance with the nature of things, it was similar to everything else, to the war, to what is going on in various colonies, to what happened in Ireland. - It was even worse, but it wasn't different - please understand that it was not different (Nałkowska 1927: 199)³.

After the Second World War we forgot about Choucas, but we remember and read, as we should, since it is an outstanding and important work,

\footnotetext{
${ }^{3}$ Nałkowska owes the fragments of Choucas about the crimes committed by Turks to an Armenian woman, whom she met in Switzerland in the Leysin-Feydey health resort: "she told me - Nałkowska notes - a lot about Armenia, its history, and the terrible recent times" (Nałkowska 1980: 168, note of 10 April 1925).
} 
Nałkowska's 1946 Medaliony (Medallions) - a collection of short stories which are largely devoted to the extermination of Jews during the Second World War. We must not, however, forget about Choucas, especially that the Jews exterminated by the Nazis did not forget about the Armenian Genocide.

In 1933, the novel Die vierzig Tage des Musa Dagh (The Forty Days of Musa Dagh) was published in Berlin. Authored by the Austrian-Jewish writer Franz Werfel, it is the most well-known work of world literature on the Armenian Genocide, which describes its heroic episode: the successful defense of a group of Armenians against Turks on Musa Dagh (Moses Mountain) in July 1915. During the Second World War, Werfel's novel was among the books that were most widely read by the citizens, or rather prisoners, of Jewish ghettos (Auron 2009: 293-311) ${ }^{4}$. In particular, the members of the Jewish resistance tried to find an analogy between Masada ${ }^{5}$ and Musa Dagh, between the tragic situation of the Jewish nation, which was bound for extermination, and the fate of the Armenians who dared take up a successful fight on the Moses Mountain. They perceived Masada as a symbol of suicide, while Musa Dagh stood for hope for salvation or, at least, honourable death. What may serve as an important literary evidence of the reception of Werfel's novel is the preface to the collection of poems written by Władysław Szlengel in the Warsaw Ghetto. Describing the deportation action which took place in January 1943, and which caused the first armed rebellion of Jews, Szlengel notes:

300 SS-men. 1,000 SS-men... The numbers have a bragging contest. At 11:30 pm the small groups in the yard turn into caravans of scared to death animals that smell a forest fire.

4 " The main place [where books can be bought in the Warsaw Ghetto - A.M.] is Leszno Street, where the best works of fashionable writers are sold in baskets. One may also find there some banned books, such as the works of Feuchtwanger, Zweig, Kautsky, Lenin, Marx, Werfel, and others", "What do the citizens [of the ghetto] read? This topic will be of interest to every Jew, and after the war it will be of interest to the whole world. The world will ask: What did the people from Musa Dagh, what did the people from the Warsaw Ghetto think, knowing that they won't be saved from death, just like the Jewish people from small towns were not saved? (...) Every serious Jew takes interest in war literature" (Ringelblum 1983: $353,399)$.

${ }^{5} \mathrm{~A}$ fortification heroically defended by Jews against Romans in 73 CE. According to Flavius Josephus, when faced with inevitable defeat, they committed mass suicide. 
The terror-lashed people with their coat collars turned up keep bumping against the walls of their cramped den. The first parties of the more bold jump over the [ghetto] wall and disappear into the city of the Aryans. Our Musa Dagh Mountain is in fire (Szlengel 2015).

Four months later, the Warsaw Musa Dagh was eventually burnt down; very few people were saved.

In Polish literature one may find more works, in which the extermination of Jews is juxtaposed with the Armenian Genocide (Morawiec 2015), including List do starego tureckiego znajomego (A Letter to My Turkish Friend) by Bohdan Gębarski, which was published in 1961. In this "angry and sad letter", or rather essay, Gębarski sheds light on the history of the Armenian Genocide perpetrated by Turks, which was almost completely unknown, or, to be more precise, forgotten in Poland in the 1960s. He also appeals to the Turkish nation to acknowledge the crimes they committed. Referring to the trial of Adolf Eichmann, which was held in Jerusalem, he writes:

But you know well that Eichmann learnt everything from you [Turks - A.M.] and what he did to Jews in the years 1942-1944 was just a large scale re-enactment of what your compatriots did to Armenians in 1915.

It was $(. .$.$) the first ever extermination of a whole nation that was planned and based on$ the rules of scientific organization of work. This massacre was prepared in every detail and had absolutely nothing to do with the "small-scale achievement" of some Abdul Hamid, who in the years 1895-96 instigated hordes of wild Kurds and the social scum against Armenians, and achieved "rather modest" results - ca. 300 thousands people killed (Gębarski 1961: 6).

Gębarski also points to other analogies between the two crimes, but does not provide more detailed arguments: "Women, children, and elders were rushed further, to death camps located between Deir ez Zor and Meskene in the Mesopotamian desert. (...) Was it in any way different from the Nazi death camps?" (Gębarski 1961: 6).

As can be seen, historians are not the only ones who treat the extermination of Jews as just one of many mass murders and put it in a broad context. For instance, at the beginning of the $21^{\text {st }}$ century, Alina Margolis, who participated in the Warsaw Ghetto Uprising, wrote an essay Moralność czasu Holokaustu (The Morality of the Holocaust Times), in which she approaches the issue under discussion from a broad perspective. Intentionally 
ignoring the legal definition of the term "genocide", which is often abused, especially by politicians, she writes: "it does not matter if the method of killing fits in the accepted definition of genocide. The same concerns the number of victims or the means that were taken. Genocide is every intentional murder of people" (Margolis 2001: 13). Afterwards, Margolis mentions "the Armenian Holocaust, which was not recognized by the world", the Jewish Holocaust, and the Holocaust in Rwanda. Alluding to the Armenian Genocide, she makes statements which sound provocative, but are not a provocation or an instance of relativizing the extermination of Jews:

A small Holocaust museum in Yerevan displays photos which make us turn our eyes away, even though our hearts have hardened over years: a father tied to a chair with a dismembered baby on his knees; next to him the child's mother with fragments of the baby's flesh stuffed in her mouth. A thought which should not be verbalized: wasn't death in a gas chamber a luxury in comparison to what is shown in this photo? (Margolis 2001: 13).

Yves Ternon stated: "It took an Auschwitz to make genocide everybody's concern" (Ternon 1981: 10). As a legal category, genocide was defined as a result of what happened (inter alia) in Auschwitz. It is crucial to remember that the author of the definition, the Polish Jew Rafał Lemkin, was inspired by the trial of Soghomon Tehlirian, who murdered Talaat Pasha, a former Turkish Minister of Interior Affairs and the initiator of the Armenian Genocide in $1915^{6}$. Furthermore, one should remember that Auschwitz, as a place and symbol of the extermination of Jews has for many years overshadowed the Armenian Genocide.

Against the background of this limited, selective historical memory (and its literary representations), Wiktor Woroszylski's 1970 poem entitled Zagłada gatunków (Extermination of the Species) is a unique text (not only in the Polish context). The eponymous "extermination" refers both to animals and to those who killed them - to people. Having mentioned numerous victims, including the Steller's sea cow, bison, and aurochs, Woroszylski states:

6 "In the 1920s, the young Lemkin was shocked by two events: the assassination of the former Turkish Minister of Interior Affairs Talaat Pasha, who was responsible for the massacre of more than a million Armenians, by S. Tehlirian, an Armenian emigrant, in Berlin in 1921 , and the murder of the ataman S. Petlura by the Jewish emigrant S. Schwarzbard in retaliation for the pogroms of Jews in Ukraine in the years 1918-1919" (Szawłowski 2008: 7). 
That's all for the natural history And now those who can imagine the Prussians rattling in the backwoods distrustful killed earlier than the aurochs They did not leave behind even a crumb of language of a pot of faith They are not to be found in Dantesque hells or paradises They are nowhere And where are the Anatolian Armenians whose blood was shed in a desert but did not make it fertile Red-skinned warriors (...) (Woroszylski 1970: 4-5).

Further in the poem, Woroszylski mentions "the Hutu people" killed in the bushland by "the Tutsi people". Who of us remembers that the extermination of the Hutu by the Tutsi which took place in Rwanda in 1994 has its antecedents? Woroszylski was most probably inspired by the massacres of Hutus by Tutsis in the 1960s in Burundi ${ }^{7}$. Afterwards, Woroszylski recalls several dozen small nations of the north and south, which "died of the food change climate change", because others wanted to:

make them happy or

punish enlighten convert convince them

to make space needed to realize various intentions

that were often very noble

(Woroszylski 1970: 5).

Woroszylski also alludes to the Jews, who were killed during the Second World War. Importantly, the list given in this poem, which can be compared to a litany of extinct species and nations, is not hierarchical. Woroszylski does not make a difference between killing animals by people and various people killing each other. The conclusion of the poem is not optimistic. It gives the impression that the poem was written by an evolutionist, and certainly by a humanist, who is overwhelmed by "history which has coalesced with nature" (Woroszylski 1977: 22):

\footnotetext{
${ }^{7}$ These massacres culminated in 1972, when a Hutu uprising led to a period of military repressions, during which Tutsi killed 100 thousand members of the Hutu community, while another 200 thousand people were forced to leave the country (Bruneteau 2005: 183). The 1972 mass killings of Hutus by Tutsis are described as "the first recorded genocide in independent Africa" (Lemarchand 2009: XI).
} 
Thus

nature which abhors a vacuum (...)

(...) The last rhinos

and numerous swallows still exist People

have their theatre Life

continues

(Woroszylski 1970: 5).

At the end, let us return to the concept of people killing each other. It is conspicuous that while in Auschwitz, the Belgian Jew Karol Zimmerring compared this infamous death camp to the system of slavery created by European (Belgian) colonizers in Congo. Before the war, Zimmerring visited Congo several times (Kubiak 1981: 122). In 1890, Congo was also visited by Józef Konrad Korzeniowski, better known as Joseph Conrad, whose Heart of Darkness is set in this country.

The novella has usually been interpreted as an allegory, which alludes to mythology, to the concepts of the original sin, initiation, the subconscious, and Bildung, and to the Nietzschean philosophy. Adam Hochschild suggests that, feeling uncomfortable because the enormity of the crime committed by white colonizers in Africa, European and American readers tried to abstract Heart of Darkness from its historical context. Thus, it was most often seen as a universal parable, rather than a text about a specific place and time. One should, however, as Hochschild argues, also treat it as a documentary novella, since, as Conrad himself stated, Heart of Darkness "is experience... pushed a little (and only very little) beyond the actual facts" (Hochschild 2012: 184).

At the turn of the $20^{\text {th }}$ century, the term genocide did not yet exist. However, the fact, or rather facts, were already in place. In the speech given on $4^{\text {th }}$ May 1898 , the British Prime Minister Lord Salisbury stated that the nations of the world can be divided into two broad categories: those who keep themselves alive and those who are bound to extinct; he added that it is natural that the former usurp the right to the territories of the latter. This attitude, which was common in those times, is accurately summarized by Kurtz, a character in Heart of Darkness, to whose making "[a]11 Europe contributed" (Conrad 1999: 77). Kurtz exclaims: "Exterminate all the brutes!" (Conrad 1999: 78). In his excellent and innovative accusatory book Utrota varenda jävel (Exterminate All the Brutes), Sven Lindqvist 
states that Conrad, not unlike his contemporaries, must have heard voices commenting on the systematic genocide that was carried out at the time (not only in Congo). He heard these voices and (as a writer who saw these things) responded to them by publishing Heart of Darkness. However, as Lindqvist further remarks, concerned about our psychological well-being, we "want genocide to have begun and ended with Nazism. That is what is most comforting" (Lindqvist 1996: 141).

It is worth contextualizing not only the Jewish Holocaust, but also the Holocaust literature - to examine it against the background of literary works, which depict other acts of genocide.

Translation into English by Katarzyna Ojrzyńska

\section{Literature}

Applebaum A., 2003, Gulag: a History, New York.

Auron Y., 2009, The Banality of Indifference: Zionism and the Armenian Genocide, New Brunswick.

Besançon A., 2000, Przekleństwo wieku. O komunizmie, narodowym socjalizmie i jedyności Zagłady, trans. J. Guze, Warszawa.

Bruneteau B., 2005, Wiek ludobójstwa, trans. B. Spieralska, Warszawa.

Bujnicki T., 1986, Wstęp, in: H. Sienkiewicz, Wybór nowel i opowiadań, Wrocław, pp. III-CXVIII.

Casas B. de las, 1992, A Short Account of the Destruction of the Indies, trans. N. Griffin, London-New York.

Chekhov A., 1967, The Island: a Journey to Sakhalin, trans. L. Terpak, M. Terpak, New York.

Chekhov A., 2002, Ward No. 6, in: A. Chekhov, Ward No. 6 and other stories, 1892 -1895 , trans. R. Wilks, London-New York.

Conrad J.,1897, An Outpost of Progress, "Cosmopolis: An International Review" No. 18, pp. 609-620; No. 19, pp. 1-15.

Conrad J., 1999, Heart of Darkness, in: J. Conrad, Heart of Darkness \& Other Stories, London, pp. 29-106.

Dostoevsky F., 1948, The House of the Dead, trans. C. Garnett, London.

Gębarski B., 1961, List do starego tureckiego znajomego, "Kierunki" No. 47, pp. 6-7.

Głowiński M., 1998, Winda - do nieba, in: M. Głowiński, Przywidzenia i figury. Małe szkice 1977-1997, Kraków.

Goldhagen D.J., 2009, Worse than War: Genocide, Eliminationism, and the Ongoing Assault on Humanity, New York. 
Hatzfeld J., 2005, Machete Season: the Killers in Rwanda Speak, New York. Herling G., 1951, A World Apart: the Journal of a Gulag Survivor, London. Herling-Grudziński G., 1953, Inny Świat. Zapiski sowieckie, London.

Hochschild A., 1998a, Les fantômes du roi Léopold II: un holocauste oublié, trans. M.-C. Elsen, F. Straschitz, Paris.

Hochschild A., 1998b, King Leopold's Ghost: a Story of Greed, Terror, and Heroism in Colonial Africa, Boston.

Hochschild A., 2012, Duch króla Leopolda. Opowieść o chciwości, terrorze i bohaterstwie w kolonialnej Afryce, trans. P. Tarczyński, Warszawa.

Jastrun M., 1962, Podobny do bogów, in: M. Jastrun, Mit śródziemnomorski, Warszawa, pp. 5-21.

Kafka F., 1987, In the Penal Colony, trans. W. Muir, E. Muir, New York.

Kiedrzyńska W., 1947, Przegląd wspomnień z obozów i więzień hitlerowskich, "Dzieje Najnowsze" issue 1, pp. 161-173.

Kubiak M., 1981, Tacy byliśmy. Wspomnienia więźnia nr 15262 z KL Auschwitz, Warszawa.

Lemarchand R., 2009, The Dynamics of Violence in Central Africa, Philadelphia.

Lindqvist S., 1996, Exterminate All the Brutes, trans. J. Tate, New York.

Lindqvist S., 2007, Terra Nullins: a Journey through No One's Land, trans. S. Death, New York.

Lukas R.C., 1986, The Forgotten Holocaust: the Poles under German Occupation, Lexington.

Margolis A., 2001, Moralność czasu Holokaustu, “Tygodnik Powszechny” No. 12, "Kontrapunkt" supplement No. 1/2, p. 13.

Midlarsky M.I., 2005, The Killing Trap: Genocide in the Twentieth Century, Cambridge-New York.

Miłosz C., 1994, Nobel Lecture, w: Nobel Lectures Including Presentation Speeches and Laureates' Biographies: Literature 1968-1980, ed. A. Sture, Singapore, pp. 190-197.

Morawiec A., 2015, Echa zagłady Ormian w literaturze polskiej, "Slavia Occidentalis" No. 2, pp. 7-30.

Nałkowska Z., 1927, Choucas. Powieść internacjonalna, Warszawa.

Nałkowska Z., 1980, Dzienniki, Vol. 3, ed. H. Kirchner, Warszawa.

Nałkowska Z., 2000, Medallions, trans. D. Kuprel, Evanston.

Olusoga D., Erichsen C.W., 2010, The Kaiser's Holocaust. Germany's Forgotten Genocide and the Colonial Roots of Nazism, London.

Ringelblum E., 1983, Kronika getta warszawskiego wrzesień 1939-styczeń 1943, ed. A. Eisenbach, trans. A. Rutkowski, Warszawa.

Różewicz T., 1976, The Survivor, in: T. Różewicz, "The survivor" and Other Poems, transl. M.J. Krynski, R.A. Maguire, Princeton, pp. 8-9.

Semelin J., 2003, Analysis of a Mass Crime: Ethnic Cleansing in the Former Yugoslavia, 1991-1999, in: The Specter of Genocide: Mass Murder in Historical Perspective, eds. R. Gellately, B. Kiernan, Cambridge, pp. 353-370. 
Sienkiewicz H., 1973, Sachem, in: H. Sienkiewicz, Western Septet: Seven Stories of the American West, trans. M. Moore Coleman, Cheshire, pp. 145-151.

Stannard D.E., 1992, American Holocaust: the Conquest of the New World, New York.

Szawłowski R., 2008, Rafat Lemkin (1900-1959) - polski prawnik twórca pojęcia ,ludobójstwo", in: Zbrodnie przeszłości. Opracowania i materiały prokuratorów IPN, vol. 2, Ludobójstwo, eds. R. Ignatiew, A. Kura, Warszawa, pp. 7-22.

Szlengel W., What I Read to the Dead, trans. A.M. Kobos, <http://www.zwoje-scrolls. com/shoah/what_I_read.html>, 01.12.2015.

Śliwowski R., 1986, Antoni Czechow, Warszawa.

Śliwowski R., 1989, Wstęp, in: A. Czechow, Opowiadania i opowieści (Wybór), trans. I. Bajkowska [et al.], Wrocław, pp. III-XCVIII.

Ternon Y., 1981, The Armenians: History of a Genocide, trans. R.C. Cholakian, Delmar.

Thucydides, 1980, The History of the Peloponnesian War, trans. R. Crawley, Franklin.

Traverso E., 2003, The Origins of Nazi Violence, trans. J. Lloyd, New York.

Werfel F., 1937, The Forty Days of Musa Dagh, trans. G. Dunlop, New York.

Woroszylski W., 1970, Zagłada gatunków, in: W. Woroszylski, Zagłada gatunków, Warszawa, pp. 3-6.

Woroszylski W., 1977, Literatura. Powieść, Paryż. 